\title{
CONSTITUTIONAL LAW AND COMMUNITY PLANNING
}

\author{
Corwin W. Jorrnson*
}

A study of the impact of constitutional law on community planning is largely an appraisal of the role of the courts in the process of planning the environment of communities. Although litigation concerning planning laws often raises issues unrelated to constitutional law, a significant characteristic of such litigation is its tendency to generate constitutional law issues. Since judicial decisions on constitutional law questions can usually be overridden only by amendment of the basic document, in contrast to decisions on common law and statutory issues, which may be altered by legislation, the courts are able to exert dominating influence upon community planning. In view of the importance of the interests at stake in determining the kind of communities in which people reside, work, rear their children, and seek fulfillment of the whole range of human aspirations, it is appropriate to consider whether, and in what respects, the courts have failed to protect deserving interests with constitutional safeguards and, on the other hand, have erected unnecessary or unwise constitutional obstacles to effective action.

Governmental regulation of economic activity and programs for economic and social betterment no longer are likely to face serious objections grounded in the United States Constitution. Attempts to have the powers of Congress construed narrowly have failed, ${ }^{1}$ and the legislative powers of the states seem almost unlimited by the due process and equal protection clauses of the Fourteenth Amendment and the contract clause of Article I, Section ro. ${ }^{2}$ However, it would be a mistake to assume that there are no important problems of constitutional law today in local planning activities. A dominant characteristic of such activities is the alteration of traditional concepts of real property ownership. There may be some basis for a belief that the range of the police power of the states is narrower when property is regulated than when freedom of enterprise is controlled. At some undefinable point, regulation of

* A.B. 1939, J.D. 194I, State University of Iowa. Member of the Iowa and California bars. Professor of Law, University of Texas. Member of the Planning Commission of the City of Austin, Texas.

${ }^{1}$ Steward Machine Co. v. Davis, 3 ro U.S. 548 (r937).

${ }^{2}$ Day-Brite Lighting, Inc. v. Missouri, 342 U.S. 421 (1952); Lincoln Federal Labor Union v. Northwestern Iron \& Metal Co., 335 U.S. 525 (I949); Goesaert v. Cleary, 335 U.S. 464 (I948). The position of the United States Supreme Court on state legislative powers was summarized recently in the following terms: "Our recent decisions make plain that we do not sit as a superlegislature to weigh the wisdom of legislation nor to decide whether the policy which it expresses offends the public welfare. The legislative power has limits ... But the state legislatures have Constitutional authority to experiment with new techniques; they are entitled to their own standard of the public welfare; they may within extremely broad limits control practices in the business-labor field, so long as specific constitutional prohibitions are not violated and so long as conflicts with valid and controlling federal laws are avoided." Douglas, J., in Day-Brite Lighting Inc. v. Missouri, stepra at 423. 
property shades into taking of property, which must be compensated, ${ }^{8}$ though it must be conceded that the instances in which the Court has determined that this point was exceeded are rare, and that there have been some examples of extreme legislative encroachments upon property which have gone uncompensated. ${ }^{4}$ The decision in Nectow v. Cambridge, invalidating a zoning ordinance as applied, has never been overruled or disapproved and could lead to future decisions adverse to planning. Planning regulations may also impinge upon interests regarded by the Court as peculiarly in need of its protection, such as the right to own and occupy land without discrimination on account of race. Obvious discrimination is clearly invalid ${ }^{8}$ and discrimination by subterfuge will surely be also. The difficult questions of the future may grow out of official action which is not directed toward racial discrimination, but which has discriminatory effects, such as segregation of economic classes through zoning. Constitutional law is an even more important factor in the state courts, which have not exhibited restraint comparable to that of the United States Supreme Court. They continue to strike down much economic and social legislation on the ground that it violates due process and other provisions of state constitutions.?

\section{Review of Cases in the United States Supreme Court}

A chronological review of community planning cases decided by the United States Supreme Court might well start in 1909 with Welch v. Swasey, ${ }^{8}$ in which the Court rejected contentions that a Massachusetts statute directing creation of two building height districts in Boston deprived landowners of property without due process of law and denied equal protection of the laws, in violation of the Fourteenth Amendment. Mr. Justice Peckham said that in determining the reasonableness of regulations of this type, "the matter of locality assumes an important aspect" and that the United States Supreme Court should attach great significance to the judgment of the highest court of Massachusetts, which had upheld the statute. However, Mr. Justice Peckham cautiously avoided a determination whether the police power could be exercised for a "merely esthetic purpose," concluding that this measure might have had as its aim the protection of residential areas from the risks of collapsing walls of tall buildings gutted by fire. The opinion contained no intimation that the regulation had any relation to the goals of preventing overcrowding

\footnotetext{
${ }^{3}$ Pennsylvania Coal Co. v. Mahon, 260 U.S. 393 (1922). What Mr. Justice Holmes said in that opinion should be compared with the following statement made by him elsewhere: "The fact that tangible property is also visible tends to give a rigidity to our conception of our rights in it that we do not attach to others less concretely clothed. But the notion that the former are excmpt from the legislative modification required from time to time in civilized life is contradicted not only by the doctrine of eminent domain, under which what is taken is paid for, but by that of the police power in its proper sense, under which property rights may be cut down, and to that extent taken, without pay." Block v. Hirsh, 256 U.S. 135, I55 (I921).

E.g., Miller v. Schoene, 276 U.S. 272 (1928).

277, U.S. I83 (1928).

'E.g., Barrows v. Jackson, 346 U.S. 249 (1953).

'See Paulsen, The Persistence of Substantive Due Process in the States, 34 MrNN. L. Rev. 9r (1950).

${ }^{8}$ 2I4 U.S. 9I (1909).
} 
of residential neighborhoods and securing adequate light and air for such sections. And, of course, traffic congestion was not yet a problem.

Three years later, the Court demonstrated that it would not always defer to the views of state courts on the reasonableness of urban land use controls. In Eubank v. Richmond, ${ }^{9}$ it held, reversing a judgment of the Supreme Court of Appeals of Virginia, that an ordinance authorizing the owners of two-thirds of the property abutting any street to establish a building line not less than five feet nor more than thirty feet from the street line was "an unreasonable exercise of the police power." The Court had no objection to building lines. What it disapproved was the placing of uncontrolled discretion in landowners to establish such lines. The Court reasoned that since the ordinance was devoid of standards, there would be no necessary relation between building lines established and the "public safety, convenience, or welfare."

In 1915, the Court had before it in two cases municipal ordinances excluding certain established businesses, livery stables in Reinman $v$. Little Rock ${ }^{10}$ and brickmaking in Hadacheck $v$. Sebastian, ${ }^{11}$ from designated portions of the city. Both were upheld, despite allegations of substantial hardship, especially severe in the case of the brickmaker, who claimed that, although the ordinance did not prohibit the removal of his clay, the clay could be made into bricks economically only if the brickmaking process occurred at the site of the deposits, and that the value of his land was reduced from $\$ 800,000$ to $\$ 60,000$. A factor which apparently influenced the Court in these cases was that livery stables and brickmaking might in some situations be nuisances. Thus, the ordinances could be viewed as legislative efforts to deal with potential nuisances. The contention that the ordinance excluding brickmaking denied equal protection of the laws because it did not also exclude other commercial enterprises from the district and because brickmaking was permitted in other parts of the city where similar conditions existed was answered by the statement that there was no proof that other "objectionable" businesses were actually present in the district from which brickmaking was excluded and that the city might in the future deal with brickyards in other localities in the community.

The attention of the Court shifted in IgI7 from livery stables and brickyards to billboards, which were prohibited by a Chicago ordinance in residential neighborhoods unless the owners of a majority of the frontage of the property on both sides of the street consented. In Thomas Cusack Co.v. Chicago, ${ }^{12}$ the ordinance was held not to violate the due process or equal protection clauses of the Fourteenth Amendment. Evidence introduced at the trial tending to show that offensive, unsanitary and combustible materials usually accumulate around billboards and that billboards afford convenient shields for immoral and criminal activities was regarded as sufficient to establish the propriety of putting billboards, as distinguished from buildings and fences, in a class by themselves. In other words, although billboards may not be

- 226 U.S. 137 (1912).

${ }^{11} 239$ U.S. 394 (I915).
${ }^{10} 237$ U.S. I7I (I9I5).
${ }_{12} 242$ U.S. 526 (I917). 
nuisances, they are likely to breed nuisance-like conditions. There was still no suggestion that a city could, within the Constitution, specify the location of certain uses of land for the sole reason that such locations were appropriate for such uses, in the judgment of local officials. The Court did, however, express a policy of judicial tolerance and left the door open for doctrinal development and expansion. ${ }^{13}$ The provision on the consent of property owners was held valid for the dubious reason that it only allowed property owners to remove a restriction and thus was unlike the consent clause held void in Eubank v. Richmond, supra, which authorized property owners to impose a restriction. The lack of substance in this distinction might reasonably have led a contemporary observer to conclude that Eubank had been tacitly overruled.

A much more significant contribution by the Court in $19 x 7$ was its decision in Buchanan $v$. Warley that a municipal ordinance creating separate residence districts for white and "colored" people was void because repugnant to the due process clause of the Fourteenth Amendment. ${ }^{14}$ There was nothing in the opinion, however, which would cast doubt upon the validity of zoning laws not involving racial segregation.

Two cases decided by the Court in I9I9 added very little, if anything, to the development of constitutional doctrine in this field. In St. Louis Poster Advertising Co. v. St. Louis, ${ }^{15}$ an ordinance regulating the size, height, and location on the lot of billboards was upheld. Mr. Justice Holmes thought that the question had already been decided in Cusack. In Pierce Oil Corp. v. Hope, ${ }^{16}$ petroleum storage tanks were added to the class composed of livery stables, brickyards, and billboards. An ordinance forbidding the storing of petroleum and related products within 300 feet of any dwelling was held not to deprive one of due process of law who had an established business the removal of which was required by the ordinance. Mr. Justice Holmes said that even if it were true as alleged (which the Court doubted) that the mode of construction of plaintiff's tanks made an explosion impossible, still the fact that the "necessarily general form of the law embraced some innocent objects . . . would not be enough to invalidate it or to remove such an object from its grasp."17

The cases reviewed to this point all involved regulatory programs. In Green v. Frazier, ${ }^{18}$ decided in 1920 , the Court passed upon an affirmative program of development. North Dakota legislation authorizing a state agency to provide urban and rural homes for residents of the state and to engage in certain other activities was challenged on the grounds that the program constituted a taking of property without due process of law and involved the use of tax revenues for private purposes. Upholding the statute, the Court conceded that the due process clause of the Fourteenth Amendment forbids state taxation for private purposes, but deferred to the determination by state authorities that the purpose in this case was public. This case and




the earlier case of Jones $v$. Portland, ${ }^{19}$ upholding a Maine statute authorizing municipalities to engage in the enterprise of selling wood, coal, and fuel, seem to have had the practical effect of eliminating any public purpose limitation in the Fourteenth Amendment upon state taxation. Specific public purpose requirements of state constitutions have been more troublesome.

A still different type of land control program was scrutinized by the Court in rg2I in Block v. Hirsh, ${ }^{20}$ holding that an act of Congress establishing rent control for the District of Columbia following World War I did not deprive landlords of property without due process of law or take their property without compensation. Speaking for the Court, Mr. Justice Holmes referred to Welch v. Swasey and related cases and declared that "if to answer one need the legislature may limit height to answer another it may limit rent." ${ }^{31}$ The four dissenting members of the Court, fearful that approval of rent control during a period of war emergency would lead to approval of an indeterminate program, insisted that there is a material distinction between rent control and use control, the latter being justified as prohibiting the "use of property to the injury of others, a prohibition that is expressed in one of the maxims of our jurisprudence."22 Similar New York legislation was upheld in Brown Holding Co. v. Feldman ${ }^{23}$ and in Levy Leasing Co. v. Siegel. ${ }^{24}$

One of the most significant contributions by the Court to community planning was its approval in 1926 of a comprehensive zoning ordinance, providing for use, height and area districts, in Euclid v. Ambler Realty $\mathrm{Co}_{.}^{25}$ It did much to dispel the hostility manifested by some state courts toward zoning and may have induced state legislatures and local governments to enact zoning legislation. An adverse decision would have been a most serious blow to planning efforts. ${ }^{26}$ The law of nuisances is to be regarded merely as a "helpful aid" rather than as limiting the scope of the police power. Changing conditions require successive definitions of that power. It now includes the "creation and maintenance of residential districts, from which business and trade of every sort, including hotels and apartment houses, are excluded," even though this means that the market value of some parcels of land is drastically reduced, it having been alleged in this case that the market value of land especially adapted for industrial development was reduced by residential zoning from $\$ 10,000$ per acre to $\$ 2,500$ per acre. However, the Court manifested reluctance to abandon nuisance concepts completely, concluding that even apartment houses may under some circumstances "come very near to being nuisances." And Mr. Justice Sutherland's opinion has been criticized on the ground that it related the provisions of the ordinance strictly "to the health and safety of the community" and ignored considerations of "the stabilizing effect upon land values, of the beautification of a city through orderly development of improvements and of aesthetic satis-

${ }^{10} 245$ U.S. 217 (19I7).

$221 d$. at 167 .

${ }^{20} 256$ U.S. 135 (r92r).

${ }^{21} I d$, at 156 .

${ }^{25}{ }_{272}$ U.S. 365 (r926).

24 258 U.S. 242 (I922).

20 Planners had concluded that effective zoning could not be achieved through the power of eminent domain. EDWARd M. BASSETT, ZONING 27 (2d ed. r940). 
faction in its bearing upon human well-being."27 But another commentator has marveled at the opinion's liberal and tolerant attitude, compared with the Court's decisions of the period invalidating other types of economic and social legislation. ${ }^{28}$

Although the zoning ordinance involved in Euclid provided for use, height and area districts, the attack there was centered upon the use restrictions. Area regulation was considered in Gorieb v. Fox, ${ }^{29}$ where the Court upheld establishment of a building line, requiring that a proposed building be set back almost thirty-five feet from the street line. The same principles justifying use restrictions were deemed to support regulations of area as well. The fact that building lines set back from streets may have the effect of minimizing cost to the local government of future street widening was not mentioned by the Court. This case is also important because it sanctioned the special permit device. The ordinance provided that the line must be at least as far from the street as that occupied by 60 per cent of the existing houses in the block, but by a proviso the city council reserved authority to make exceptions and permit the erection of buildings nearer the street. In this case the council, acting under the proviso, established the line for one lot at thirty-four and two-thirds feet in a block where the established line was slightly over forty-two feet. This discretion of the city council was deemed distinguishable from giving similar discretion to neighboring property owners, and also presumably different from vesting it in an administrative agency. Though abuses of discretion by the city council would not be countenanced, the existence of discretion to establish different lines for individual lots is not unconstitutional.

The Court was careful to point out in its Euclid opinion that, due to the nature of the allegations of the plaintiff landowner, the decision there amounted to little more than approval of zoning in principle. Specific zoning ordinance provisions and applications of zoning ordinances to particular parcels of land might still be held unconstitutional. Later in the same term, in Zahn v. Board of Public Works, ${ }^{30}$ a residential classification of a section of the city which was largely undeveloped, but which contained scattered business uses and embraced land adjoining a major thoroughfare, was upheld on the theory that it was not clearly unreasonable. But in the next term, the Court demonstrated that the caveat in the Euclid opinion was to be taken seriously. Reversing a judgment of the Supreme Judicial Court of Massachusetts, the Court held invalid in Nectow $v$. Cambridge ${ }^{31}$ the inclusion of certain land within a residential district. The land in question was a portion of a larger tract of vacant land separating residential uses from industrial uses. The evident purpose of the zoning authorities was to protect the established residential character of the lands lying on the other side of intersecting streets bordering the vacant tract. A master appointed by the trial court found that "no practical use can be made of

${ }^{27}$ Miner, Some Constitutional Aspects of Housing Legislation, 39 ILI. L. REv. 305, 31 r (1945).

${ }^{28}$ Ribble, The Due Process Clause as a Limitation on Municipal Discretion in Zoning Legislation, I6 VA. L. Rev. 689, 699 (I930).
${ }^{20} 274$ U.S. 603 (I927).
${ }^{80} 274$ U.S. 325 (1927).
${ }^{31}{ }_{277}$ U.S. 183 (1928). 
the land in question for residential purposes" and that "districting of the plaintiff's land in a residence district would not promote the health, safety, convenience and general welfare of that part of the defendant City." Despite these findings, the Supreme Judicial Court of Massachusetts did "not feel that the zoning line established was whimsical, without foundation in reason." ${ }^{32}$ The reversal by the United States Supreme Court was based primarily upon the finding of the master, "supported, as we think it is, by other findings of fact," that the challenged classification would not promote the traditional police-power objectives. The Court could see no reason why the boundary between the residential and industrial districts should not be moved Ioo feet. The opinion fails to reveal the scope of the Court's study of the effect of the judicially created boundary upon the neighborhood or upon the zoning plan for the city.

One might have supposed that the meaning of Nectow was that the Court intended to supervise closely exercises of the recently approved zoning power. But the immensity of such a task makes this supposition absurd. Indeed, the Court has never again passed upon a zoning case. The Court's purpose, then, must have been to guide the state courts. Yet, the standards set forth for their guidance are not clearly discernible. Since the master found that no practical use could be made of the land in question for residential purposes, it might be concluded that the Constitution requires that if land is zoned, the classification must permit a use for which the land is adapted. The difficulty with this is that the Court did not appear to attach any significance to that finding of the master. We are left with the generalization that the classification must promote the "health, safety, convenience and general welfare of the inhabitants of the part of the city affected." Apart from its vagueness, this standard, if a serious attempt were made to apply it, would imperil most zoning boundaries. While it is easy to demonstrate the beneficent effects of a comprehensive zoning ordinance upon a city, it is almost impossible to prove that an isolated segment of a zoning line will promote traditional police power objectives. Surely the Court was not instructing the state courts that the proper procedure in zoning cases is to appoint a master and accept his conclusion as to con-

32 "If there is to be zoning at all, the dividing line must be drawn somewhere. There cannot be a twilight zone. If residence districts are to exist, they must be bounded. In the nature of things, the location of the precise limits of the several districts demands the exercise of judgment and sagacity. There can be no standard susceptible of mathematical exactness in its application. Opinions of the wise and good well may differ as to the place to put the separation between different districts. Seemingly there would be great difficulty in pronouncing a scheme for zoning unreasonable and capricious because it embraced land on both sides of the same street in one district instead of making the center of the street the dividing line. ... No physical features of the locus stamp it as land improper for residence. Indeed, its accessibility to means of transportation, to centers of business, and to seats of learning, as well as its proximity to land given over to residence purposes, give to it many of the attributes desirable for land to be used for residence. . . . Courts cannot set aside the decision of public officers in such a matter unless compelled to the conclusion that it has no foundation in reason and is a mere arbitrary or irrational exercise of power having no substantial relation to the public health, the public morals, the public safety, or the public welfare in its proper sense. These considerations cannot be weighed with exactness. That they demand the placing of the boundary of a zone one hundred feet one way or the other in land having similar material features would be hard to say as matter of law." Nectow v. Cambridge, 260 Mass. $441,447,448,157$ N.E. 618, 620 (1927). 
formity of the questioned zoning with the police power. A charitable critic might say that all the Court was trying to do in Nectow was to caution the state courts to be vigilant in correcting abuses of the zoning power, and that the Court's language was deliberately vague because the Court appreciated the difficulty of applying specific criteria uniformly in the solution of problems where local conditions assume great importance.

The Court had declared in Euclid that its decision there did not preclude subsequent successful attack upon either applications of zoning ordinances to particular lands or upon specific provisions of typical zoning ordinances. Nectow was an i1lustration of the former. The latter was illustrated by Washington ex rel. Seattle Title Trust Co. v. Roberge, ${ }^{33}$ in which the Court revisited the problem of consent clauses, this time holding invalid a provision that "A philanthropic home for children or for old people shall be permitted in first residence district when the written consent shall have been obtained of the owners of two-thirds of the property within four hundred feet of the proposed building." Cusack was distinguished on the ground that the proposed building was not like billboards or other uses which "by reason of their nature are liable to be offensive." It now seemed clear that the distinction between consent clauses which impose restrictions and those which only remove restrictions, if not repudiated, would rarely be applicable.

Excess condemnation received the Court's attention in 1930. Condemning land for the immediate purpose of widening a street, the City of Cincinnati undertook to acquire more land than would be occupied by the widened street. The constitutional question was whether the excess land was acquired for a public purpose if the sole reason for its acquisition was recoupment of the expense of street widening through the resale of neighboring lands, enhanced in value by the improvement. The Court deemed it well established that the due process clause of the Fourteenth Amendment requires that the power of eminent domain be exercised for a public purpose, but declined to pass upon the issue in this case for the reason that the state court judgment adverse to the city was supportable on the ground that the condemnation proceedings failed to conform to applicable state law. ${ }^{34}$ There was nothing in the opinion suggesting that the practice in question would be favored.

Thirteen years passed without an important decision by the United States Supreme Court in this field. Then came decisions upholding national rent control programs during and after World War II. ${ }^{35}$ It was also held that Congress has power to provide low-cost public housing and may exempt from local taxation projects owned by the Federal Public Housing Authority. ${ }^{86}$ In Queenside Hills Realty Co. v. Saxl, ${ }^{37}$ the Court shored up local efforts to deal with slum housing by its holding that a New York law requiring installation of expensive fire prevention

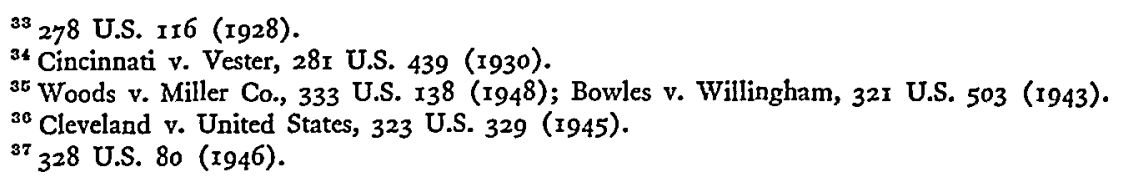


sprinkler systems in lodging houses did not violate the due process or equal protection clauses of the Fourteenth Amendment, even as applied to buildings equipped with other types of fire protection devices alleged to be adequate. The decision was hardly unexpected. The "public use" limitation upon eminent domain again engaged the Court in United States ex rel. T.V.A. v. Welch, ${ }^{38}$ a case which did not directly involve community planning, but which had implications for it. Upholding condemnation by the T.V.A. of lands not strictly necessary for a proposed dam and reservoir, the Court manifested extreme reluctance to upset condemnation proceedings for want of a public use, and apparently all but three of the Justices were willing to regard as final a determination by Congress that a use is public.

The recent historic decisions on racial restrictive covenants are well known. ${ }^{39}$

The most recent case is Berman v. Parker, ${ }^{40}$ decided during the $1954-55$ term, holding that condemnation of property pursuant to the District of Columbia Redevelopment Act of 1945 was for a public purpose and was consistent with due process of law, and that the delegation of authority in the act was qualified with sufficient standards. There was unanimous concurrence in Mr. Justice Douglas' opinion that the police power of Congress over the District of Columbia, deemed as extensive as the police power of the states, comprehends a wide discretion in the acquisition and redevelopment of large blocks of land. An attempt to hobble this discretion by limiting it to elimination of slums, defined narrowly as the existence of conditions injurious to the public health, safety, morals, and welfare, was brushed aside. The standards contained in the act in question were considered adequate to sanction the redevelopment of not only slums, but also "the blighted areas that tend to produce slums," including particular lots which are not blighted at all. The police power, the Court indicates, is even broader, embracing redevelopment for the general objective of achieving a "better balanced, more attractive community." The Court does its best to make it clear that the "traditional applications" of the police power-" "public safety, public health, morality, peace and quiet, law and order"-are merely illustrations of the police power, not limitations upon it. Aesthetic and spiritual values may also be sought through exercises of this power. As for the power of eminent domain, the "role of the judiciary in determining whether that power is being exercised for a public purpose is an extremely narrow one." ${ }^{\text {41 }}$ It was concluded that the acquisition of land for redevelopment might be done by private enterprise subject to public control, the use of private enterprise being regarded merely as a means to an end within the power of Congress.

Berman v. Parker is of the utmost importance. Not only does it sanction a

${ }^{38} 327$ U.S. 546 (1946).

${ }^{30}$ Barrows v. Jackson, 346 U.S. 249 (1953); Shelley v. Kraemer, 334 U.S. I (1948); Hurd v. Hodge, 334 U.S. 24 (1948).

6348 U.S. 26 (1954). Four years earlier, in a similar case, involving the Urban Redevelopment Law of Pennsylvania, the Court had affirmed the judgment below (upholding the law) with a memorandum opinion, citing the Welch case, supra note 38 . Burt v. Pittsburgh, 340 U.S. 892 (r950).

${ }^{11}$ Berman v. Parker, 348 U.S. 26, 31, 32, 35 (1954). 
planning device which is the most promising yet attempted at the local level, but it also manifests a sympathetic and tolerant attitude toward community planning in general. The broad reading of the opinion is that the Constitution will accommodate a wide range of community planning devices, as states and local governments seek new ways to meet the pressing problems of community growth, deterioration, and change.

This conclusion is also borne out by the record of the United States Supreme Court in the line of cases reviewed here, commencing with Welch v. Swasey. The only decisions adverse to planning programs were Eubank v. Richmond, Seattle Title Trust Co. $v$. Roberge, and Nectow v. Cambridge. None of these could fairly be considered major setbacks for community planning. Consent clauses in land use regulations, invalidated in Eubank $v$. Roberge, are not essential and are probably undesirable. ${ }^{\mathbf{2}}$ It was not a planning device, but only the zoning classification of a particular tract of land, which was held void in Nectow. The Court handled the problem there badly, but not even the most ardent planner would deny that abuses in zoning can and do occur or assert that the courts should ignore such abuses. Perhaps the most serious criticism which can be leveled at the performance of the Court in this series of cases is that the overly cautious language in some of the opinions may have deterred legislative advances and have induced restrictive action by state courts.

A full appraisal of the role of the Court requires consideration not only of its decisions, but also of the instances in which it has avoided decision by refusing to review lower court judgments. During the past six terms of the Court (r949-1950 to I954-r955, as of January r, r955), the Court has declined to review, by dismissing appeals or denying petitions for certiorari, twenty-one cases which might fairly be regarded as local planning cases. In all of these except one, the judgments below upheld statutes, ordinances or actions by local officials. The single exception was a holding below that the granting of a variance by a zoning board of appeals was invalid. ${ }^{43}$ Thus, the record of the Court in abstaining from review of local planning cases during this period has been decidedly favorable to planning programs.

${ }^{12}$ See Note, The State Courts and Delegation of Public Authority to Private Groups, 67 Hanv, L. REv. 1398 (1954).

${ }^{43}$ Board of Zoning Appeals of Hempstead v. Clark, 340 U.S. 933 (195I). The other cases: McCarthy v. Manhattan Beach, 348 U.S. 8I7 (r954) (zoning); Jayne v. Detroit, 348 U.S. 802, 889 (1954) (parking meters); Kaskel v. Impellitteri, 347 U.S. 934 (1954) (urban redevelopment); Gazan v. Corbett, 346 U.S. 822 (1953) (zoning); Carlor Co. v. Miami, 346 U.S. 82 I (I953) (eminent domain); Elsato Real Estate, Inc. v. Miami Beach, 346 U.S. 820 (I953) (zoning); Lionshead Lake, Inc. v. Wayne, 344 U.S. 9rg (I953) (zoning); Veal v. Leimkuehler, 344 U.S. $9 \times 3$ (1953) (zoning); White v. Chicago Land Clearance Commission, 344 U.S. 824 (1952) (urban redevelopment); Mundet Cork Corp. v. New Jersey, 344 U.S. 8I9 (I952) (smoke control); Flora Realty \& Investment Co. v. Ladue, 344 U.S. 802 (r952) (zoning); Cherrywood Apts., Inc. v. United States, 342 U.S. 902 (r952) (public housing); Newark v. New Jersey Turnpike Authority, 342 U.S. 874 (195I) (eminent domain); Dallas County Water Control and Improvement District No. 3 v. Dallas, 340 U.S. 952 (I95I) (municipal annexation); Prunk v. Indianapolis Redevelopment Commission, 340 U.S. 950 (195I) (urban redevelopment); Marsh v. El Dorado, 340 U.S. 940 (195I) (municipal annexation); Standard Oil Co. v. Tallahassec, 340 U.S. 892 (1950) (zoning); Corporation of Latter Day Saints v. Porterville, 338 U.S. 805 (1949) (zoning); Glissmann v. Omaha, 339 U.S. 960 (r950) (zoning); Keyes v. Madsen, 339 U.S. 928 (1950) (compulsory building demolition). 


\section{Pattern of State Court Decisions}

In contrast to the paucity of community planning cases decided by the United States Supreme Court, the state courts have poured out a flood of decisions, many of which involve issues of constitutional law, state and national. In general, planning, as well as other types of social and economic programs, have not fared as well in the state courts as in the United States Supreme Court. At the hands of some state courts, broad concepts of constitutional law-substantive due process, equal protection of laws, separation of powers, nondelegation of legislative power, public purpose in taxation and spending, public use in eminent domain-have become rigid and narrow. Possibly most of the adverse decisions are properly viewed as irritants rather than as crippling blows to planning. At least since Euclid, it appears that there has been general judicial acceptance of the principle that local governments may attempt to control the physical condition of their communities, that, within limits, public decisions as to land use shall prevail over private decisions, and that even substantial losses in some land values caused by community plans need not be compensated. The unfavorable decisions have involved particular planning programs, usually those thought to impose excessive sacrifices, discrimination or unfair procedures, and sometimes programs involving features regarded as novel or as specifically forbidden by constitutional provisions. A few illustrative cases, selected from the areas of planning administration, planning instrumentalities, and planning decisions, will be considered briefly.

\section{A. Planning Administration}

Ideally, there should be insistence upon constitutional procedures which are sufficiently stringent to promote fairness, but not so inflexible or impracticable as to stifle effective action. One of the more frequently raised questions is whether there is an improper delegation of power to an administrative agency.

This challenge, no longer a potent threat to acts of Congress, is still formidable when state legislation and local ordinances are being tested. ${ }^{44}$ It can usually be overcome, in advance, by a careful statement of standards, which may satisfy the courts that administrative power is thereby restrained, but which in reality afford hardly any protection against arbitrary action. ${ }^{45}$

The incidence of invalidations of statutes and ordinances on this ground may be a commentary on the quality of legislative draftsmanship at state and local levels. There are some instances of judicial punctiliousness, however, which it is doubtful even the most meticulous draftsman would have anticipated. For example, an Illinois ordinance was held invalid which directed the building inspector to refuse a building permit for the erection of a building not having its principal frontage upon a "street or officially approved place," on the ground that the ordinance contained no definition of "officially approved place."46 A Florida zoning ordinance was not saved from

\footnotetext{
"KenNeth C. Davis, Administrative Law c. 2 (I95x).

"Ibid.

“Schimpff v. Norvell, 368 Ill. 325 , I3 N.E.2d 960 ( 1938$)$.
} 
attack recently by an elaborate specification of details. It provided that in a Business "A" District, "no operation shall be carried on which is injurious to the operating personnel of the business or to the other properties, or to the occupants thereof by reason of the objectionable emission of cinders, dust, dirt, fumes, gas, odor, noise, refuse matter, smoke, vapor, vibration, or similar substances or conditions." The court, stressing the word "objectionable," construed the ordinance as being conditioned upon the objections of neighbors, and thus equated it with consent clauses. ${ }^{\mathbf{4 7}}$ Since ordinances can easily be amended, the effect of such decisions may not be extremely serious. But, of course, before the ordinance can be amended, a few enterprisers may have escaped regulation and have established "vested" rights, and it is conceivable that frequent invalidations of planning ordinances would have a demoralizing effect upon planning efforts.

On occasion, the state courts have condemned as inadequate standards which were about as specific as they could be, in light of the nature of the administrative task. Perhaps the best known example is Welton $v$. Hamilton, ${ }^{48}$ holding invalid the grant of power to a board of zoning appeals to vary the application of the ordinance in instances where "there are practical difficulties or unnecessary hardship in the way of carrying out the strict letter of the ordinance ... so that the spirit of the ordinance shall be preserved. ..." If the standard were much more specific than this, it is doubtful that a board of zoning appeals could perform satisfactorily the function expected of it, the essence of which is the handling of unforeseen problems. This decision seemed especially serious since it invalidated the enabling statute as well as the ordinance. Yet, perhaps surprisingly, Welton $v$. Hamilton has not actually prevented the exercise of broad administrative power to grant zoning variances during the more than twenty years since it was handed down, according to a recent study of the Illinois situation. ${ }^{40}$ An innocuous amendment of the enabling statute, substituting "particular hardship" for "unnecessary hardship" and requiring findings of fact, apparently has sufficed. ${ }^{50}$ Indeed, boards of zoning appeals in Illinois, as well as elsewhere, have been criticized for over-leniency. ${ }^{51}$

\section{B. Planning Instrumentalities}

The banning of a useful planning tool is likely to be a more serious matter than either the insistence upon excessive standards of administration or the invalidation of particular planning decisions.

After the Euclid decision in I926, the state courts which had not already done so came around to the conclusion that zoning, at least in principle, was compatible with their state constitutions, as well as with the United States Constitution. ${ }^{\text {22 }}$ The

${ }^{47}$ Phillips Petroleum Co. v. Anderson, 74 So.2d 544 (Fla. 1954). However, the action taken under the ordinance in this case did appear to be arbitrary.

48 344 Ill. 82, 92, I76 N.E. 333, 337 (I931), discussed in Freund, Note, 26 ILL. L. Rev. 575 (1932).

${ }^{\circ} \mathrm{Sec}$ Dallstream and Hunt, Variations, Exceptions and Special Uses, 1954 U. of ILL. LAw Fonum 2r3.

${ }^{50} \mathrm{ld}$. at 217.

53 I EMMetr C. Yokley, Zoning LaW and Practice 25, 26 (2d ed. I953). However, use zoning was not upheld in New Jersey until after the constitution was amended, and in a few other states constitutional amendment was deemed desirable. EDward M. BAssetr, Zoning I7-19 (2d ed. 1940). 
judicial testing of paricular zoning devices, however, seems to be a continuing task. This is due, in part, to the emergence of new types of zoning controls from the efforts of local governments to improve upon the early ordinances.

Classification schemes have been tested, and some have failed. Thus, for example, it has been held that churches cannot be excluded from residence districts, ${ }^{53}$ or even subjected to general off-street parking requirements which would have the effect of preventing use of a lot for church purposes. ${ }^{54}$ To so hold is to allow the problems generated by churches in residential neighborhoods-traffic congestion, traffic hazards, the cutting off of light and air, noise-to be overshadowed by an exaggerated concern for religious freedom. The exclusion of private schools from use districts in which public schools are permitted has been condemned. ${ }^{55}$ Similarly, the Supreme Court of Illinois recently held void an ordinance permitting grade schools in an apartment district but excluding nursery schools. ${ }^{56}$ On the other hand, the Supreme Court of New Jersey refused to disturb an ordinance creating a residential district which included high schools and grade schools, but from which colleges were excluded. ${ }^{57}$ An off-street parking requirement for apartment houses was invalidated because it was thought to be discriminatory in that the ordinance contained no similar requirement for other structures, such as rooming houses and hotels, creating similar parking problems. ${ }^{58}$ An ordinance excluding residences from industrial areas was held unreasonable and void, in so far as it was applicable to land suitable for residential use and not adapted to industrial uses. ${ }^{50}$ Some attempts to exclude certain uses entirely from a municipality have failed, ${ }^{60}$ while others have succeeded. ${ }^{61}$ Such efforts are manifestations of the broader problem of governmental boundaries which do not correspond with appropriate planning boundaries. The worst aspect of this situation is the risk that the interests of persons who have no voice in the shaping of policy will be substantially affected. Judicial vigilance is therefore justified. But until regional planning is accomplished, the striking down of programs of the established governmental units may create planning vacuums.

In view of the trend in zoning ordinance revision in the direction of the creation

${ }^{63}$ Sherman v. Simms, I43 Tex. II5, I83 S.W.2d 4I5 (1944). For other cases in accord, see 2 Yokzey, Zoning LaW and Practice, \$222 (2d ed. I953). Contra: Corporation of Latter Day Saints v. Porterville, go Cal. App.2d 656, 203 P.2d 823 (r949), appeal dismissed, 338 U.S. 805 (1949).

" Board of Zoning Appeals v. Jehovah's Witnesses, II7 N.E.2d II5 (Ind. Sup. Ct. 1954).

${ }^{65}$ State v. Northwestern Preparatory School, 228 Minn. 363, 37 N.W.2d 370 (I949). Contra: State ex rel. Wisconsin Lutheran High School Conference v. Sinar, 65 N.W.2d 43 (Wis. 1954).

${ }^{50}$ City of Chicago v. Sachs, $x$ Ill. 2 d 342, II5 N.E.2d 762 (I953). Since this ordinance was of the permissive type (i.e., the uses listed for each district are permitted, not prohibited, uses), it is possible that the failure to mention nursery schools was inadvertent.

67 Yanow v. Seven Oaks Park, II N.J. 34I, 94 A.2d 482 (1953).

${ }^{58}$ Ronda Realty Corp. v. Lawton, 414 Ill. $3^{13}$, IxI N.E.2d 3 Io (1953).

${ }^{50}$ Corthouts v. Newington, I40 Conn. 284, 99 A.2d II2 (1953).

${ }^{60}$ People ex rel. Trust Co. of Chicago v. Skokie, 408 Ill. 397,97 N.E.2d 3 ro (I95I) (drive-in theatres); Baris Lumber Co. v. Secaucus, 20 N.J. Super. 586, 90 A.2d I30 (r952) (storage and sale of used building materials, lumber, mason materials, plumbing materials, and heating materials). Both ordinances, however, appeared to have been aimed at the plans of particular enterprisers.

${ }^{\circ 2}$ Duffcon Concrete Products v. Cresskill, I N.J. 509, 64 A.2d 347 (I949) (all heavy industry). 
of more and narrower districts, ${ }^{62}$ a recent New York decision that a parking district (within which the only permitted uses were parking and storage of automobiles and operation of service stations) was invalid as applied is significant. ${ }^{.3}$ Although the narrow holding there was only that the classification of particular property was void, the decision seems to preclude the zoning of any property within a parking district if the surrounding land has business buildings upon it and if the property in question would be suitable for similar more intensive business uses-the very situation in which a parking district is needed. Some support for narrow districts is found in a recent California decision upholding a beach recreational district, within which the only permitted structures were lifeguard towers, wire fences, and small signs. ${ }^{\text {o* }}$

Regulations which tend to encourage the establishment of exclusive residential districts-"economic segregation"-constitute one of the most controversial aspects of urban planning today. Criticism on this ground has been aimed at ordinances establishing minimum building cost, minimum height, architectural conformity, minimum cubic content of buildings, minimum floor area, and minimum lot area ${ }^{65}$ Attention has been focused recently upon requirements of minimum floor space for residences, which have been invalidated in Michigan and Pennsylvania, for lack of sufficient relation to the public health, safety, morals or general welfare, ${ }^{06}$ but upheld in New Jersey and Texas. ${ }^{67}$ When it has been urged that minimum standards of house size have a bearing upon health, especially mental health, by discouraging overcrowding, it has been pointed out by critics that the size of a house has no relation to the number of people who live in it, and that if overcrowding is to be prevented, control of occupancy is the solution. By way of rebuttal, advocates of this form of regulation assert that occupancy controls are impracticable. ${ }^{68}$ To this writer, it seems that the police power ought to comprehend crude and unsuccessful programs as well as perfect and successful ones. Moreover, if the people of a community decide through democratic processes that attractive and expensive residential neighborhoods are to be promoted and preserved, it would be most improper for a court to set aside that decision in the name of "democracy" or "liberalism." There

${ }^{62}$ Babcock, Classification and Segregation Among Zoning Districts, 1954 U. of ILL. Law Forum x86, I87.

${ }^{63}$ Vernon Park Realty v. Mount Vernon, I2I N.E.2d 517 (N.Y. I954).

${ }^{86}$ McCarthy v. Manhattan Beach, 41 Cal.2d 897, 264 P.2d 932 (1953), cert. denied, 348 U.S. 817 (1954).

${ }^{60}$ For collection and discussion of cases, see Note, Zoning: Permissible Pturposes, 50 Cot. L. Rev. 202, 204-207 (1950). A three-acre minimum lot area requirement was upheld in Flora Realty \& Investment Co. v. Ladue, 362 Mo. I025, 246 S.W.2d 77 I (1952), appeal dismissed, 344 U.S. 802 (1952); and a fiveacre requirement was approved in Fischer v. Bedminster, II N.J. 194, 93 A.2d 378 (1952).

${ }^{B B}$ Hitchman v. Oakland, 329 Mich. 33I, 45 N.W.2d 306 (I95I) (which cites earlier Michigan cases in accord); Appeal of Medinger, 377 Pa. 217, I04 A.2d Ix 8 (1954).

${ }^{67}$ Lionshead Lake, Inc. v. Wayne, to N.J. I65, 89 A.2d 693 (1952), appeal dismissed, 344 U.S. $9 \times 9$ (x953); Thompson v. Carrollton, 211 S.W.2d 970 ('Tex. Civ. App. 1948)

${ }^{88}$ The arguments on both sides are skillfully presented in Haar, Zoning for Minimum Standards: The Wayne Township Case, 66 Harv L. Rev. 105x (1953); Nolan and Horack, Hou Small a House? -Zoning for Minimutm Space Requirements, 67 HaRv. L. Rev. 967 (1954); Haar, Wayne Tounship: Zoning for Whom?-In Brief Reply, 67 HaRv. L. REv. 986 (1954); Williams, Zoning and Housing Policies, 10 J. Housing 94 (1953). 
is no resemblance between the latest pronouncements of the United States Supreme Court on the scope of the police power and the statement by the Supreme Court of Pennsylvania in its opinion invalidating a minimum floor area requirement that "neither aesthetic reasons nor the conservation of property values or the stabilization of economic values in a township are, singly or combined, sufficient to promote the health or the morals or the safety or the general welfare of the township or its inhabitants or property owners. ..."69

Retroactive zoning has incurred judicial disfavor. There are several instances of invalidation of ordinance provisions requiring termination of non-conforming uses which could not qualify as "nuisances."70 Although prospective restrictions on use may cause a greater financial loss to landowners than retroactive limitations, the latter are apparently thought to be more severe. There are indications, however, that carefully drafted termination provisions allowing reasonable periods for "amortization" will be upheld. ${ }^{71}$

Community development programs, as well as regulatory activities, have also been subjected to constitutional attack. Since these programs are effected through exercises of the powers of eminent domain, taxation, and spending, they have had to satisfy the public purpose and public use requirements of state constitutions. Public housing for low-income groups was approved everywhere except in Ohio, where it was held that the properties of local housing authorities were not exempt from local property taxation because such properties were not "used exclusively for any public purpose."72 The recent cases support the acquisition and operation of public parking lots, although a recent California case invalidated a municipal plan to turn over operation of such a facility to a private operator without reserving control over rates. ${ }^{73}$ A multitude of other municipal enterprises have also been upheld. ${ }^{74}$ The most important of the community development programs-urban redevelopment-involving the public acquisition, assembly, and redevelopment of sections of the community, has been upheld in nearly all states, Florida and Georgia being notable exceptions. ${ }^{75}$ The courts in the latter two states were of the view that the vice of the programs was the ultimate sale or lease of the assembled land to private enterprisers. Their reasoning was surprising, to say the least. The Supreme Court of Florida asserted in apparent earnestness that if "the only purpose is to remove or abate a blighted area, the

${ }^{\circ 0}$ Appeal of Medinger, 377 Pa. 2I7, 226, 104 A.2d 118, 122 (1954).

${ }^{70}$ The leading case is Jones v. Los Angeles, 2 II Cal. 304, 295 Pac. I4 (1930). Recent cases: Akron v. Chapman, 160 Ohio St. 382, II6 N.E.2d 697 (1953); Corpus Christi v. Allen, I52 Tex. 137, 254 S.W.2d 759 (1953).

${ }^{71}$ Standard Oil Co. v. Tallahassee, I83 F.2d 4 ro (5th Cir. 1950), cert. denied, 340 U.S. 892 (I950); City of Los Angeles v. Gage, 127 Cal. App.2d 538, 274 P.2d 34 (I954); see Note, 67 Harv. L. Rev. 1283 (1954).

${ }_{73}$ The cases are reviewed in Miner, supra note 27. The Ohio cases are criticized in McDougal and Mueller, Public Purpose in Public Housing: An Anachronism Reburied, 52 Yale L. J. 42 (1942).

${ }^{73}$ City and County of San Francisco v. Ross, 270 P.2d 488 (Calif. App. 1954), which cites other cases on the subject at $49 \mathrm{x}$.

14 See Comment, Public Land Ownership, 52 YALE L. J. 634, 641-644 (I943).

${ }^{75}$ The cases are collected in Papadinis v. Somerville, I2r N.E.2d 714, 7I7 (Mass. 1954). 
police power is ample."76 The Supreme Court of Georgia, when told that slums contribute to juvenile delinquency, retorted: "We think juvenile delinquency exists on both sides of the railroad tracks and, if this should be sufficient reason for the use of the power of eminent domain, some of the most exclusive sections of our cities could be razed to make room for industrial development." ${ }^{\text {"77 }}$ In states where redevelopment laws have been upheld, new questions can be expected to arise from time to time as techniques are refined and improved. An advanced program in Illinois, the Illinois Urban Community Conservation Act of 1953, authorizing the redevelopment of "conservation areas" (i.e., deteriorating urban areas which are likely to become slum and blighted areas), was recently upheld. ${ }^{78}$

In connection with public land acquisition, it should be noted that there are some decisions adverse to certain techniques for facilitating planning for future public land uses. While it is established that a city may prohibit the erection of buildings in mapped streets, and thereby minimize the cost of future condemnation, ${ }^{70}$ the application of this technique to parks and playgrounds was held in a recent case to be a taking without just compensation. ${ }^{80}$ Yet, if the city decides to condemn sites for future public uses long in advance of the time of contemplated use, it may be frustrated by constitutional or statutory requirements of "necessity," as in a recent Michigan case holding that condemnation of a school site which might not be used for thirty years was not necessary. ${ }^{81}$

\section{Planning Decisions}

The term "planning decisions" is used here to refer to applications of planning tools to particular situations, such as the inclusion of certain land within a certain zoning district (the zoning map), the rejection of a proposed subdivision plat or the redevelopment of a particular area. The invalidation of such decisions may leave the planning instrumentalities intact. However, judicial review may be so severe that the instrumentalities cease to be useful.

The need for vigilance by the judiciary is probably especially great here. The influence of special interests is perhaps more likely to affect particular planning decisions than the formulation of broad policies or the adoption of planning instrumentalities. It may also be true that the former are not usually preceded by as thorough study as the latter. Another factor bearing upon the determination of proper judicial review is the nature of the governmental entity whose action is to be reviewed. Nearly all planning decisions are made by governing bodies of local gov-

${ }^{78}$ Adams v. Housing Authority of Daytona Beach, 60 So.2d 663, 666 (Fla. I952).

${ }_{77}$ Housing Authority of Atlanta v. Johnson, 209 Ga. 560, 563, 74 S.E.2d 891, 894 (1953).

${ }^{78}$ People ex rel. Gutknecht v. Chicago, I2I N.E.2d 791 (Ill. Sup. Ct. 1954); Zizook v. MarylandDrexel Neighborhood Redevelopment Corporation, I2I N.E.2d 804 (Ill. Sup. Ct. I954).

${ }^{70}$ Headley v. Rochester, 272 N.Y. 197,5 N.E.2d 198 (1936).

${ }^{80}$ Miller v. Beaver Falls, 368 Pa. I89, 82 A.2d 34 (I95I). The use of zoning for the same purpose has also been disfavored, 2700 Irving Park Building Corp. v. Chicago, 395 Ill. 138,69 N.E.2d 827 (1946).

${ }^{81}$ Board of Education v. Baczewski, 65 N.W.2d 810 (Mich. 1954). But cf. Carlor Co., Inc. v. Miami, 62 So.2d 897 (Fla. 1953), cert. denied, 346 U.S. 821 (1953). 
ernments and citizen-staffed planning commissions, aided by expert staffs to an extent which varies widely among localities. While the same bodies also formulate broad policies and select planning tools, in doing so they are likely to rely upon the experiences of other localities and the research and recommendations of reputable private and public planning organizations. Some of the broad policy-making is done by the state legislature, usually in the form of enabling acts. These acts, having a broader political base and being more difficult to amend than local ordinances, are entitled to greater judicial respect.

Most of the adverse zoning cases are invalidations only of the ordinance as applied. These cases are numerous. In some states, particularly Illinois, judicial antipathy has been so pronounced that it may have caused serious damage to the zoning process. ${ }^{82}$ Due to the infinite variety of fact situations presented in the cases and the vagueness of the rationalization in court opinions, generalization about them is difficult. However, it is apparent that many of the decisions are based upon extremely narrow conceptions of the zoning power. A fairly common characteristic of the cases is the emphasis upon reduction in the value of the land in question caused by the zoning map. ${ }^{83}$ Yet, even substantial value declines for some tracts are inevitable consequences of zoning, as was recognized and sanctioned by the United States Supreme Court in Euclid v. Ambler Realty Co. Concern for this factor led the highest court of New York to insist recently upon the unbelievably strict criterion that zoning is void "whenever the zoning ordinance precludes the use of property for any purpose for which it is reasonably adapted."84 If given general application, this criterion would make zoning impossible. A dissenting opinion in the New York case states more orthodox standards: a zoning ordinance is confiscatory only when it so restricts the use of property that it cannot be used for any reasonable purpose or when it restricts the property to a use for which it is not adapted. Even these standards may be too strict. They impede long-range planning when they are applied to land which is not presently, but may be in the future, adapted for uses permitted by its zoning classification. An example is an earlier New York case holding invalid residential classification of land in a largely undeveloped area on the ground that the property could not, then or in the immediate future, be used profitably for residential purposes. ${ }^{85}$

Perhaps some of the adverse decisions might have been avoided by more careful zoning. A common cause of judicial dissatisfaction is the adjacent location of use districts containing grossly incompatible uses, as where a zoning boundary separates

${ }^{8}$ See Babcock, The Illinois Supreme Court and Zoning: A Study in Uncertainty, 15 U. of CHr. L. Riev. 87 (1947).

83 E.g., Reschke v. Winnetka, 363 Ill. 478, 2 N.E.2d 718 (1936).

${ }^{84}$ Vernon Park Realty v. Mount Vernon, 307 N.Y. 493, I2I N.E.2d 517, 519 (1954).

${ }^{85}$ Arverne Bay Construction Co. v. Thatcher, 278 N.Y. 222, 15 N.E.2d 587 (1938). Conceivably, this case might have been decided differently had the city itself not been responsible in part for the factors making this land unsuitable for residential purposes, by maintaining an incinerator and open sewer in the vicinity. 
residential and industrial districts. ${ }^{86}$ Utilization of narrower and more numerous use districts, as well as mapping which provides gradual transition from highly restricted districts to slightly restricted districts, may alleviate this problem.

Unique problems are raised by zoning map amendments, as distinguished from the original mapping and re-mapping of large sections of the community. Typically, amendments are sought by property owners who desire to devote their property to a use not permitted in the use district within which the property has been placed, but who are unable to obtain variances or special exceptions from the zoning board of appeals. The courts are understandably chary of such changes, which may have been motivated more by concern for individual property owners than for the welfare of the community. ${ }^{87}$ Some of the opinions come close to raising a presumption against their validity. ${ }^{88}$ Undiscriminating application of such a presumption to all amendments would be unwise. The earlier mapping, probably having been done on a large scale, may not have taken into consideration adequately certain small areas. Unanticipated developments may have occurred. Indeed, failure to amend an originally valid mapping ordinance after a substantial change in conditions may result in an adjudication that it is now invalid. ${ }^{89}$ Amendments initiated by planning commissions probably deserve greater deference than those proposed by interested landowners. Although the courts have not stressed the point, it would seem that they should be unusually suspicious of amendments adopted by the local governing body contrary to the recommendation by the planning commission. ${ }^{00}$ In addition, the scope and throughness of the study and deliberation preceding the amendment are especially relevant factors for judicial review, although these also have been seldom stressed in the opinions. A step in the right direction was taken in a recent opinion basing the court's judgment invalidating an amendment, in part, upon the absence of findings or reasons by the planning commission and upon the fact that the "atmosphere of the proceeding was not conducive to calm deliberation," it having been shown that several "organized bus loads of angry property owners filled the hearing

\footnotetext{
${ }^{80}$ Reschke v. Winnetka, 363 Ill. 478,2 N.E.2d 718 (1936) was such a case.

${ }^{87}$ Grant v. McCullough, 270 S.W.2d 3 I7 (Tenn. I954) is not atypical. There the court, invalidating an amendment changing the use classification of one lot, owned by an elderly widow with a dependent invalid son, from residential to commercial, said: "No basis for this action can be conjured other than that it emanated from a strong desire to help this good lady. . . . It was inconsistent with the general ordinance on the subject, and gave to Mrs. Grant a privilege withheld by the general law from others in a situation like unto that of Mrs. Grant." Id. at 3 Ig.

${ }^{88}$ Penning v. Owens, 65 N.W.2d 83 I (Mich. 1954); Cresskill v. Dumont, 15 N.J. 238 , 104 A.2d 44I (I954); Clifton Hills Realty Co. v. Cincinnati, 6o Ohio App. 443, 2 I N.E.2d 993 (1938); Wcaver v. Ham, I49 Tex. 309, 232 S.W.2d 704 (r950). But compare Keller v. Council Bluffs, 66 N.W.2d Ir3 (Iowa 1954), which upheld an amendment changing classification of three lots from A Residence to B Residence, thereby permitting a convalescent home, despite the facts that these lots were surrounded by $A$ Residence District land, that there had been no change in conditions in the area since the previous zoning, and that the effect of the change was to sanction a previous non-conforming use which apparently had been illegal.

${ }^{80}$ Skalko v. Sunnyvale, I4 Cal.2d 213, 93 P.2d 93 (I939).

${ }^{90}$ Despite such circumstance, however, amendments were upheld in the following cases: Louisville v. Puritan Apartment Hotel Co., 264 S.W.2d 888 (Ky. r954); Goddard v. Stowers, 272 S.W.2d 400 (Tex. Civ. App. 1954).
} 
room, and frequently interrupted witnesses and counsel by booing and hissing, or applauding."

\section{Conclusion}

It is difficult to measure the impact of the adverse state court decisions upon local planning. Although they are numerous and are accompanied by opinions severely circumscribing the range of planning action, many of the unfavorable decisions strike at aspects which could not fairly be deemed essential to effective planning. This is especially true of invalidations of particular planning decisions, such as the placing of certain land within a zoning district, which should be distinguished from invalidations of planning tools. The former, being peculiarly susceptible to improper pressures, should be subjected to close judicial scrutiny.

The role of the United States Supreme Court is much different from that of the state courts. It can do no more than pass upon the broader issues. It does not deserve strong criticism for its relatively passive role. When it has acted, it has nearly always given its approval to the planning programs which have come before it. In so far as state court decisions are based upon state constitutions, the United States Supreme Court is powerless to reverse them, of course. However, the Court may influence the attitudes of the state court judges, as it apparently did with its opinion in Euclid v. Ambler Realty Co. Perhaps the Court could now make a similar contribution by taking another case involving the zoning of particular land, as in Nectow $v$. Cambridge. In view of zoning experience since that decision, the Court might now be able to indicate more clearly the relevant criteria. It would also be helpful if the Court would speak up on the status of certain planning tools which some state courts have questioned, such as the termination of nonconforming uses. This writer would not criticize the Court for its failure to review and reverse state court decisions upholding planning devices regarded by some as accomplishing "economic segregation." There is no less reason for the Court to defer to legislative judgments on debatable issues of community planning than in the areas of business and labor. It does not follow that because "economic segregation" may lead to racial segregation, the former is entitled to the judicial antipathy accorded the latter. No doubt many economic and social policies of government affect unevenly various economic classes, and thus may bear more heavily upon some races than upon others, but an attempt to trace such relationships and make them determinative of the constitutionality of legislative programs would be to return to the approach of the pre-I937 Court.

${ }^{91}$ American University v. Prentiss, II3 F. Supp. 389, 392 (D.D.C. 1953), aff'd, 214 F.2d 282 (D.C.Cir. 1954). This case is one of the rare instances of amendment to place a tract in a more restrictive classification, at the request of neighbors. For elaboration of the thesis that in passing upon zoning the courts should place "greater emphasis upon the procedural aspects and upon the absence of political or neighborhood pressures," see Babcock, supra note 82 at ro0-105. 